\title{
Artikel
}

\section{Uit- en overlevering van EU-burgers bij overtreding van het kartelverbod - op het snijvlak van straf- en mededingingsrecht}

\author{
Mr. W.W. Geursen en mr. J. Boonstra-Verhaert*
}

\section{Inleiding}

In Nederland wordt het mededingingsrecht (nog steeds) bestuursrechtelijk afgedaan. De strafrechtelijke handhaving van dit rechtsgebied heeft de laatste jaren in andere landen een opmars gemaakt; ook in verschillende lidstaten van de Europese Unie. Hoewel in Nederland het mededingingsrecht een 'strafrechtelijk verleden' kent, werd deze handhavingsvorm weinig benut en/of was deze weinig succesvol en is hiervan afscheid genomen. ${ }^{1}$ Dat Nederland overtredingen van de mededingingswet nu niet strafrechtelijk sanctioneert, wil echter niet zeggen dat aan mededingingsrechtelijke overtredingen voor Nederlanders geen strafrechtelijke risico's kleven. Indien dergelijke overtredingen door Nederlandse onderdanen in het buitenland effect hebben, omdat daar bijvoorbeeld de klanten van een kartel zijn gevestigd, ${ }^{2}$ kunnen Nederlanders alsnog - zij het in het buitenland - tegen strafrechtelijke vervolging en een veroordeling aanlopen.

Mr. W.W. Geursen is werkzaam als Senior Legal Adviser bij De Brauw Blackstone Westbroek en is als buitenpromovendus verbonden aan de Vrije Universiteit. Mr. J. Boonstra-Verhaert is initiator van actualiteitenwebsite BijzonderStrafrecht.nl, werkzaam als Senior Legal Adviser bij De Brauw Blackstone Westbroek en is als eindredacteur verbonden aan TBS\&H.

1. Met de Wet Economische Mededinging; Zie daarover nader: R. de Bree, 'Mededingingsrecht en strafrecht: hernieuwde kennismaking', $M \& M$ 2006-7, p. 206

2. Of om een andere reden rechtsmacht voor de strafbare feiten bestaat van een andere staat.
Dit heeft de Nederlandse ex-directrice van Martinair Cargo, Meta Ullings - de 'godin van de vracht' ${ }^{3}-$, recentelijk aan den lijve ondervonden. Zij werd verdacht van betrokkenheid bij het zogenoemde luchtvrachtkartel. Volgens zowel de Europese Commissie ${ }^{4}$ als de United States Department of Justice ('DOJ') $)^{5}$ zouden verschillende luchtvaartmaatschappijen tussen 2001 en 2006 onderlinge prijsafspraken hebben gemaakt over bijvoorbeeld brandstofheffingen en andere toeslagen. Tijdens haar vakantie op Sicilië is Ullings aangehouden en door Italië - na vergeefs beroep - uitgeleverd aan de Verenigde Staten van Amerika ('VS'). Eenmaal in de VS heeft zij schuld bekend aan overtreding van het Amerikaanse kartelverbod en is zij veroordeeld tot 14 maanden gevangenisstraf $f^{6}$ en betaling van een geldboete van USD 20.000 .

Volgens de $\mathrm{DOJ}^{7}$ was zij al tien jaar "voortvluchtig en is deze uitlevering 'a reminder that individuals who violate U.S. antitrust laws and seek to evade justice will find no

3. Zo werd zij blijkbaar onder vliegers genoemd; "14 maanden cel voor "'godin van de vracht"', De Telegraaf, 25 januari 2020.

4. Besluit van de Europese Commissie van 9 oktober 2020 in zaak AT. 39258 - Airfreight.

5. Persbericht van de Department of Justice van 9 april 2009, 'Three International Airline Companies Agree to Plead Guilty to Price Fixing on Air Cargo Shipments', www.justice.gov/opa/pr/three-international-airlinecompanies-agree-plead-guilty-price-fixing-air-cargo-shipments.

6. Met aftrek van de door haar doorgebrachte tijd in uitleveringsdetentie in Italië.

7. Persbericht van de Department of Justice van 13 januari 2020, 'Former Air Cargo Executive Extradited From Italy for Price-Fixing', www.justice.gov/opa/pr/former-air-cargo-executive-extradited-italyprice-fixing. 
place to hide'. ${ }^{8}$ Naar alle waarschijnlijkheid was zij al die tijd 'gewoon' in Nederland. Had zij niet eerder al door Nederland kunnen worden uitgeleverd aan de VS? Het lijkt erop dat de VS geen uitleveringsverzoek heeft gedaan aan Nederland, maar dat zij internationaal was gesignaleerd, doordat de $\mathrm{VS}^{9}$ haar op de Interpollijst van gezochte personen had geplaatst en dat het uitleveringsproces in gang werd gezet doordat zij ging reizen. Martinaircollega Frank de Jong, die rechtstreeks aan haar rapporteerde en verantwoordelijk was voor de verkoop (en volgens de DOJ daarmee ook voor het in rekening brengen van de kartelprijzen), ging haar al in 2009 voor $^{10}{ }^{10}$ nadat werkgever Martinair reeds in 2008 een schikking had getroffen met de DOJ. ${ }^{11}$ De schikking tussen Martinair en de DOJ beschermde expliciet tegen vervolging van zijn werknemers met uitzondering van Ullings en De Jong.

Deze zaak doet de vraag rijzen welke strafrechtelijke risico's Nederlandse onderdanen lopen bij mededingingsrechtelijke overtredingen die afnemers buiten Nederland duperen.

\section{Mededingingsbeperkingen in het Nederlandse strafrecht: strafbare biedkartels}

Sinds de inwerkingtreding van de Mededingingswet in 1998 ligt het primaat van handhaving tegen mededingingsbeperkende gedragingen in beginsel in het bestuursrecht. Wel is er de nodige interactie met het strafrecht, bijvoorbeeld waar het gaat om beboeting van natuurlijke personen: zij die feitelijk leiding hebben gegeven aan de mededingingsrechtelijke overtreding kunnen worden beboet. ${ }^{12}$

Wanneer sprake is van een mededingingsbeperkende gedraging, kunnen daarnaast commune strafbare feiten zijn gepleegd, zoals valsheid in geschrift (art. $225 \mathrm{Sr}$ ), witwassen (art. 420bis Sr), deelname aan een criminele organisatie (art. $140 \mathrm{Sr}$ ) en oplichting (art. $326 \mathrm{Sr}$ ). Strafrechtelijke vervolging voor dergelijke commune feiten behoort dus wel tot de mogelijkheden, maar is tot op heden weinig succesvol geweest. ${ }^{13}$

Wat betreft de mededingingsbeperkende gedraging zelf, is er in het strafrecht welgeteld één bepaling die vervolging tegen oneerlijke concurrentie mogelijk maakt, namelijk art. 328bis Sr. Deze bepaling luidt als volgt:

\begin{abstract}
'Hij die, om het handels- of bedrijfsdebiet van zichzelf of van een ander te vestigen, te behouden of uit te breiden, enige bedrieglijke handeling pleegt tot misleiding van het publiek of van een bepaald persoon, wordt, indien daaruit enig nadeel voor concurrenten van hem of van die ander kan ontstaan, als schuldig aan oneerlijke mededinging, gestraft met gevangenisstraf van ten hoogste een jaar of geldboete van de vijfde categorie.'
\end{abstract}

Art. 328bis $\mathrm{Sr}$ stelt een specifieke vorm van bedrog strafbaar, namelijk 'bedriegelijke handelingen (...) paaronder zijn te verstaan alle handelingen, welke geschikt zijn om den normalen mensch, die de gebruikelijke mate van oplettendheid betracht, in een valschen maan te brengen' ${ }^{14}$ Daarmee biedt het artikel bescherming tegen oneerlijke mededinging in ruime zin, ${ }^{15}$ zoals misleidende recla-
8. Speech van R.A. Powers, Deputy Assistant Attorney General DOJ van 19 februari 2020, 'A Matter of Trust: Enduring Leniency Lessons for the Future of Cartel Enforcement', www.justice.gov/opa/speech/file/ 1250291/download.

9. R. Hesse, 'Towards a Closer World: A Look Back at International Cooperation in the Obama Administration', Speech tijdens het Fordham Competition Law Institute's 43rd Annual Conference on International Antitrust Law and Policy in New York, 23 september 2016, www.justice.gov/opa/speech/acting-assistant-attorney-general-renatahesse-antitrust-division-delivers-remarks.

10. Persbericht van de US Department of Justice van 29 april 2009, 'Dutch Airline Executive Agrees to Plead Guilty for Fixing Prices on Air Cargo Shipments - Martinair Holland Executive Agrees to Serve Jail Time', www.justice.gov/opa/pr/dutch-airline-executive-agrees-plead-guiltyfixing-prices-air-cargo-shipments. De Jong was de tweede Nederlander ooit die wegens een kartelinbreuk in een Amerikaanse gevangenis een straf uitzat. De twijfelachtige eer om de eerste Nederlander ooit te zijn, was weggelegd voor Rick van Westenbrugge, voormalig directeur van JO Tankers B.V. uit Spijkenisse wegens een kartel inzake bulkzeetransport van vloeibare stoffen; Plea agreement van 8 januari 2004, www.justice.gov/atr/case-document/plea-agreement-419.

11. Plea agreement van 22 juli 2008 , www.justice.gov/atr/case-document/ plea-agreement-243.
12. In 2007 werd een schakelbepaling opgenomen in de Mededingingswet die verwees naar feitelijk leidinggevenden in art. 51, lid 2, onder $2 \mathrm{Sr}$; Wet van 28 juni 2007, houdende wijziging van de Mededingingswet als gevolg van de evaluatie van die Wet, Stb. 2007, 284; zie nader: W.W. Geursen, 'Wijziging van de Mededingingswet door de Evaluatiewet', Actualiteiten Mededingingsrecht 2007/7, p. 131. Thans verloopt de schakeling via art. 5:1 lid 3 Awb.

13. R. de Bree, 'Mededingingsrecht in het strafrecht: "Law in the making"?', Actualiteiten Mededingingsrecht 2008, p. 211 e.v.

14. HR 20 oktober 1930, ECLI:NL:HR:1930:339.

15. Alhoewel strafrechtelijke handhaving van oneerlijke concurrentie tegenwoordig als te omslachtig wordt beschouwd en eerder naar civielrechtelijke remedies wordt gezocht; F. Henning-Bodewig, Unfair competition law: European Union and member states, Alphen a/d Rijn: Kluwer Law International 2006, p. 10. 
me ${ }^{16}$ inbreuk op handelsnamen ${ }^{17}$ en ook mededingingsbeperkende gedragingen.

De laatste strafzaak - en overigens de eerste in decennia - waarin art. 328bis Sr een noemenswaardige rol $^{18}$ speelde, betrof een rechtshulpverzoek dat werd gedaan aan de Nederlandse autoriteiten in een Duits strafrechtelijk onderzoek naar een biedkartel. ${ }^{19}$ De Oberstaatsanwalt bij het Landgericht Frankfurt am Main deed in 1982 een verzoek om kleine rechtshulp aan de officier van justitie te Den Haag. Het verzoek strekte tot 'huiszoeking, inbeslagneming van stukken, uitlevering daarvan naar de [Bondsrepubliek Duitsland (BRD)] en tot verhoor van degene tegen wie deze dwangmaatregelen maren gericht' ${ }^{20}$ Het verzoek had betrekking op Piet H., een in Nederland woonachtige natuurlijk persoon, die betrokken zou zijn geweest bij prijsafspraken bij een Duitse aanbesteding; een biedkartel of bidrigging. $\mathrm{H}$. zou een voorname rol hebben gespeeld bij het tot stand komen van prijsafspraken tussen aannemers die werkzaam zijn in de bouw in de BRD; namens H. werden deze eufemistisch prijsregulerende afspraken genoemd. De aanbestedingen betroffen omvangrijk publieke projecten, waarmee veel geld gemoeid was. Het vermoeden bestond dat $H$. een voorname rol had vervuld bij het organiseren van prijsafspraken. H. zou voorlichting hebben gegeven en regelingen hebben

16. Misleidende advertenties bij meubelverkoop; Valse indruk van aansluiting bij het Rijksbotercontrolestation; HR 29 september 1924, NJ 1924, 1078. HR 2 februari 1931, NJ 1931, 1061. Een misleidende aanduiding van kandidaatdeurwaarder HR 25 januari 1937, NJ 1937, 726 en meer recent op een website vermelden dat een dienstverlener beschikt over een certificaat voor asbestverwijdering, terwijl dat niet zo is; Gerechtshof Den Bosch, 22 mei 2012, ECLI:NL:GHSHE:2012:BW6237.

17. Een voorbeeld van toepassing van deze bepaling betrof de in 1928 ontslagen directeur van de 'Naamlooze Vennootschap Fabrieken van Rolluiken en Zonweringen voorheen J. Senft \& Co'. Hij zette een concurrerende zaak op onder de naam 'Senft \& Co W. K. ... en Zonen v/h dir. Glazenwasscherij en Jalouziënfabriek' en liet dit zo ook opnemen in voor het destijds in een groot aantal exemplaren verspreide adresboek voor 's-Gravenhage, Scheveningen en Loosduinen. Dit betrof een misleidende vermelding, een bedrieglijke handeling, waarvan verdachte de eventuele vergissing van lezers van het adresboek had moeten voorzien. Een en ander leidde tot een succesvolle strafrechtelijke vervolging van overtreding van art. 328bis $\mathrm{Sr}$ en de oplegging van een geldboete van vijf en twintig gulden; HR 20 oktober 1930, ECLI:NL:HR:1930:339.

18. Nog recenter is het beklag over het niet-vervolgen van Rabobank, haar toenmalige bestuurders alsook werknemers in de Libor-affaire door de Stichting Justitia Distributiva. Zij betoogde onder meer dat sprake zou zijn van overtreding van art. 328bis $\mathrm{Sr}-$ naast het plegen van een veelheid aan andere delicten. Het gerechtshof Den Haag maakte hier weinig woorden aan vuil en overwoog dat op basis van het voorhanden zijnde materiaal onvoldoende concrete aanknopingspunten aanwezig waren voor dergelijke strafrechtelijke verwijten en strafvervolging (hof Den Haag 19-05-2015, ECLI:NL:GHDHA:2015:1204). Overigens zijn Rabobank en enkele van haar werknemers in de Libor-affaire wel strafrechtelijk vervolgd voor overtreding van het Amerikaanse kartelverbod; DOJ, 'Rabobank Admits Wrongdoing in Libor Investigation, Agrees to Pay $\$ 325$ Million Criminal Penalty', persbericht 29 oktober 2013; DOJ, 'Former U.K. Rabobank Derivatives Trader Pleads Guilty to LIBOR Interest Rate Manipulation Charges', persbericht 23 maart 2015; DOJ, 'Two Former Rabobank Traders Convicted for Manipulating U.S. Dollar, Yen LIBOR Interest Rates', persbericht 5 november 2015; DOJ, 'Former Rabobank Derivatives Trader Pleads Guilty for Scheme to Manipulate LIBOR Benchmark', persbericht van 7 juli 2016.

19. HR 12 juni 1984, ECLI:NL:HR:1984:AC2550.

20. Ibid opgesteld, een handeling die op zodanige wijze is ingericht, dat zij in haar uitwerking geacht kan worden misleidend te zijn ten opzichte van de Duitse overheid, die daarop niet bedacht behoefde te zijn. ${ }^{21}$

Het rechtshulpverzoek was gedaan op grond van het Europees rechtshulpverdrag. ${ }^{22} \mathrm{Op}$ grond van art. 5 van dat verdrag is dubbele strafbaarheid vereist voor het bieden van de verzochte rechtshulp. ${ }^{23}$ De aan $H$. verweten feiten zijn naar Duits recht strafbaar (par. 263 StGB). Uiteindelijk oordeelde de Hoge Raad in deze zaak dat 'de aan $H$. vermeten feiten [ook] naar Nederlands recht strafbaar (...) [zijn] gesteld in art. 328bis Sr'. ${ }^{24} \mathrm{Het}$ handelen overeenkomstig een kartelafspraak is 'een bedrieglijke handeling tot misleiding van de aanbesteder' ${ }^{25}$ Ook was voldaan aan het vereiste dat 'enig nadeel voor concurrenten van hem of van die ander kan ontstaan'. Volgens de Hoge Raad valt de aanbestedende dienst onder de reikwijdte van die 'ander' en lijdt die schade als gevolg van de prijsafspraken. ${ }^{26}$ Buiten het specifieke geval van biedkartels bij aanbestedingen, zouden ook 'normale' kartels waarin bijvoorbeeld concurrenten onderling verkoopprijzen of een marktverdeling afspreken onder art. 328bis Sr kunnen vallen. Die kartels benadelen hoogstwaarschijnlijk ook hun afnemers (de 'ander') en zouden dan net zo goed als bedrieglijk kunnen worden aangemerkt. Overigens hoeven niet alleen afnemers te worden benadeeld, ook concurrenten kunnen worden benadeeld bij een overtreding van het kartelverbod. ${ }^{27}$

Art. 328bis Sr bestaat nog steeds en omvat nog steeds (bied)kartels, ook al wordt de bepaling niet actief ingezet bij de handhaving tegen mededingingsbeperkende gedragingen. Doornbos ${ }^{28}$ noemt de bepaling zelfs een dode letter. Fuchs en Hein ${ }^{29}$ zoeken de verklaring daarvoor in het boetemaximum van $€ 87.000^{30}$ voor natuurlijke personen en $€ 870.000$ voor rechtsperso-

21. Ibid

22. Europees Verdrag aangaande de wederzijdse rechtshulp in strafzaken, Straatsburg 20 april 1959. Inmiddels lopen verzoeken van lidstaten tot overlevering via het Kaderbesluit EAB; dat is in plaats gekomen van de uitleveringspraktijk die nog wel voor derde landen geldt.

23. Zie daarover nader bijvoorbeeld: 'Dubbele strafbaarheid in het Nederlandse strafrecht; Notitie over het vereiste van dubbele strafbaarheid in relatie tot internationale strafrechtelijke samenwerking en rechtsmacht', TK 2003-2004, 29.451, nr. 1.

24. HR 12 juni 1984, ECLI:NL:HR:1984:AC2550, NJ 1985, 174, r.o. 7.6.

25. Ibid., r.o. 7.4

26. Ibid., r.o. 7.5

27. Zie bijvoorbeeld Gerecht van de EU, 22 oktober 1997, gevoegde zaken T-213/95 en T-18/96, Stichting Certificatie Kraanverhuurbedrijf (SCK) en Federatie van Nederlandse Kraanverhuurbedrijven (FNK) / Commissie, ECLI:EU:T:1997:157, r.o. 145, waarbij voornamelijk buitenlandse concurrenten werden uitgesloten van de Nederlandse markt en HvJEU 11 september 2014, C-67/13 (Groupement des cartes bancaires (CB)), ECLI:EU:C:2014:2204, r.o. 80 e.v. waarbij het kartelgedrag mogelijk resulteerde in het uitsluiten van nieuwkomers op de betaalkaartenmarkt.

28. D.R. Doorenbos, 'Strafrecht baat niet, schaadt wel', M\&M oktober 2010, nr. 5, p. 167 e.v.

29. T. Fuchs en D.P. Hein, 'Straffeloos sanctioneren: een keuze voor de weg van de minste juridische weerstand?', OSP, nr. 4/2014

30. Art. 23 lid 4, vijfde categorie, per 1 januari 2020 
nen. ${ }^{31}$ Dat staat in schril contrast tot de maximumboete van $€ 900.000$ voor natuurlijke personen en $10 \%$ van de groepsomzet voor ondernemingen op grond van art. 57 Mw; dat kan bij een kartel van lange(re) duur en recidive zelfs oplopen tot maximaal $80 \%$. Wel kan op grond van art. 328bis $\mathrm{Sr}$ een gevangenisstraf van maximaal één jaar worden opgelegd en een ontzetting uit het beroep op grond van art. $339 \mathrm{Sr}$; zie over een mogelijk beroepsverbod bij kartels ook de analyse van Doornbos ${ }^{32}$ (in het Verenigd Koninkrijk ${ }^{33}$ komt een beroepsverbod wegens overtreding van het kartelverbod overigens vaker voor).

Ondanks het geringe gebruik van deze bepaling bij strafrechtelijke handhaving in Nederland, kan deze wel leiden tot de conclusie dat er sprake is van dubbele strafbaarheid, zoals de zaak Piet $H$. aantoont. Daarom kan deze bepaling die een dode letter lijkt te zijn, voor sommigen toch de nagel aan hun doodskist betekenen.

\section{Ontneemt Mededingingswet strafrechtelijke grondslag en strafbaarheid?}

De vraag kan worden gesteld of er nog steeds sprake is van dubbele strafbaarheid nu Nederland sinds 1998 kartelovertredingen bestuursrechtelijk handhaaft onder de Mededingingswet. Zou niet kunnen worden beargumenteerd dat de Mededingingswet de lex specialis is en art. 328bis Sr lex generalis? En als dat zo is, zou dan de Mededingingswet boven art. 328bis $\mathrm{Sr}$ gaan, in dier voege dat dat ook de strafbaarheid ontneemt aan een kartelovertreding?

Iets vergelijkbaars probeerde Piet $H$. in de eerder besproken zaak ook aan te voeren. Namens hem is aangevoerd dat kartelovertredingen in 1984 ook al niet werden gehandhaafd onder art. 328bis $\mathrm{Sr}$, maar onder de Wet Economische Mededinging (WEM); overtreding daarvan was een economisch delict. Namens Piet $H$. werd aangevoerd dat dat als lex specialis voorrang zou moeten hebben op de lex generalis van art. 328bis Sr. De Hoge Raad schoof dat argument terzijde en oordeelde daarover het volgende:

'Het feit, voorzien bij art. 2 Wet economische mededinging en strafbaar ingevolge art. 1 onder 3\% $W E D$, verhoudt zich tot het bepaalde in art. 328bis $\mathrm{Sr}$ niet als een bijzondere ten opzichte van een algemene strafbepaling, omdat de aard van de in eerstgenoemde bepaling neergelegde norm, verplichtend tot een administratieve handeling jegens de overheid, geheel verschillend is van de aard van het bedrogsdelict van art. 328bis $S r{ }^{34}$

Sinds 1998 is de Mededingingswet in werking getreden 'ter vervanging van de Wet economische mededinging' zo leert ons de preambule van de Mededingingswet. Zou de thans geldende Mededingingswet dan wel te gelden hebben als een lex specialis ten opzichte van art. 328bis $\mathrm{Sr}$ waardoor er alsnog geen strafrechtelijke grond zou bestaan? Of zou de meest voor de hand liggende redenering moeten zijn: als art. 328bis Sr naast de WEM kon bestaan, dan ook naast de Mededingingswet die de WEM vervangt.

Er is al wel duidelijkheid over de vraag of de WEM en de Mededingingswet naast elkaar kunnen bestaan en toegepast. Art. 106 Mededingingswet maakt een temporele splitsing tussen het oude en nieuwe regime: het oude strafrechtelijke regime van de WEM is van toepassing op overtredingen van voor de inwerkingtreding; op latere overtredingen is de Mededingingswet van toepassing. Desalniettemin trachtte het OM de leden van het glazenwasserskartel strafrechtelijk te vervolgen in plaats van de (toen nog) Nederlandse Mededingingsautoriteit (NMa). Daarover oordeelde het Hof Den Haag het volgende:

'Wat betreft het [kartelgedrag] doet zich naar het oordeel van het hof een mettelijk vervolgingsbeletsel voor. (...) Door de belastingontduiking, de valsheid in geschrift, en het mitwassen in het kader te plaatsen van het (volgens de Mededingingswet in beginsel illegale) georganiseerde verband van zelfstandige glazenmassersondernemingen, ontstaat een zodanige samenhang met de (...) vastgestelde mededingingsrechtelijke feiten, dat het gehele feitencomplex wordt geregeerd door de Mededingingswet, en de behandeling van de zaak voor mat betreft het eerste feit mettelijk is voorbehouden aan de bevoegde kartelautoriteit (NMa). Dit vloeit voort uit het bepaalde in de artikelen 106 Mededingingswet, 1, lid 2, en 55 Wetboek van Strafrecht en 7 EVRM. Op grond van de genoemde keuze van de metgever mocht de verdachte erop vertroumen dat hij niet in een strafproces zou porden betrokken als verdachte van deelneming aan een criminele organisatie. Daarom gaat een dergelijke manier van optreden van het openbaar ministerie ook in tegen beginselen van een goede procesorde en van een behoorlijke strafrechtspleging, waaronder het vertroumensbeginsel.

De vastgestelde rechts- en metsschending acht het hof dermate fundamenteel dat zulks niet anders dan door nietontvankelijkverklaring van het openbaar ministerie kan porden gesanctioneerd voor pat betreft het eerste feit. ${ }^{35}$
34. HR 12 juni 1984, ECLI:NL:HR:1984:AC2550, r.o. 7.2.

35. Gerechtshof 's-Gravenhage 21 mei 2008, ECLI:NL:GHSGR: 2008:BD3383, r.o. 7. 
Vervolgens heeft de (toen nog) $\mathrm{NMa}^{36}$ de overtreding van het kartelverbod door de glazenwassers op grond van de Mededingingswet alsnog beboet - zij het gering en ook niet alle glazenwassers. Volgens de NMa stonden het ne bis in idem-beginsel, het una via-beginsel en het vertrouwensbeginsel een tweede handhavingsprocedure door de NMa niet in de weg. Art. 106 Mededingingswet, zoals ook geïnterpreteerd door het Haagse hof, maakt een temporele splitsing tussen het oude strafrechtelijke WEM-regime en nieuwe administratiefrechtelijke regime. Er bestaat evenwel geen temporele splitsing tussen art. 328bis $\mathrm{Sr}$ en de Mededingingswet. Derhalve zouden die twee bepalingen op gelijke voet kunnen staan, net zoals de Hoge Raad bij Piet $\mathrm{H}$. oordeelde ten aanzien van de WEM en art. 328bis Sr. Dat leidt dan tot de conclusie dat een feitencomplex van een biedkartel zowel onder art. 328bis $\mathrm{Sr}$ kwalificeert als onder het kartelverbod van art. 6 Mededingingswet. Als een kartel in een ander land ook strafbaar is gesteld, leidt dat tot de in het internationale strafrecht vereiste dubbele strafbaarheid. De Mededingingswet neemt die strafbaarheid onzes inziens niet weg.

\section{Uit- en overlevering bij kartels}

Als die mededingingsrechtelijke gedraging dan buiten Nederland effect heeft - bijvoorbeeld omdat de klanten van een kartel daar zijn gevestigd - kan dat buitenland strafrechtelijke vervolging instellen en kan het tot een veroordeling leiden. Die staat kan Nederland dan verzoek tot uit- of overlevering doen. Daarbij dient in gedachte te worden gehouden dat hiervoor is geconcludeerd dat deelname an een (bied)kartel naar Nederlandse maatstaven strafbaar is onder art. 328bis $\mathrm{Sr}$. Hierna zullen wij ingaan op mogelijke uitlevering aan de VS - als één van de belangrijkste derde landen waar kartelovertredingen strafrechtelijk wordt gehandhaafd, zoals bleek bij Ullings - en overlevering naar een andere EU-lidstaat.

\subsection{Uitlevering aan de VS}

Wanneer het gaat om uitlevering door Nederland aan de VS zijn meerdere verdragen van toepassing. Enerzijds is dat de multilaterale overeenkomst tussen de Europese Unie ('EU') en de $\mathrm{VS}^{37}$ (hierna: EU-VS-uitleveringsverdrag) en anderzijds het bilaterale uitleveringsverdrag tussen het $\left(\right.$ gehele $\left.^{38}\right)$ Koninkrijk der Nederlanden en de
VS (hierna: uitleveringsverdrag NL-VS). ${ }^{39}$ Volgens art. 3 lid 1 onder a van het EU-VS uitleveringsverdrag gaat dat multilaterale verdrag voor op bepalingen uit bilaterale verdragen die 'uitsluitend' uitleveren op grond van lijstfeiten, maar daar lijkt in de relatie NL-VS geen sprake van te zijn om de volgende redenen.

Het Uitleveringsverdrag NL-VS kent voor wat betreft de feiten waarvoor uitlevering kan plaatsvinden een combinatie van twee systemen: ${ }^{40}$ het enumeratiestelsel, waarbij de delicten waarvoor uitlevering mogelijk is uitputtend worden opgesomd op een lijst (lijstfeiten), en het eliminatiestelsel, waarbij alle delicten die naar het recht van de verzoekende en de angezochte staat met vrijheidsstraf zijn bedreigd in beginsel tot uitlevering kunnen leiden mits deze strafbedreiging een bepaald minimum te boven gaat (dubbele strafbaarheid). De combinatie van beide stelsels werkt praktisch zo uit dat allereerst een uitleveringsverplichting bestaat voor feiten die naar het recht van verzoekende en angezochte staat met een vrijheidsstraf van meer dan een jaar zijn bedreigd. ${ }^{41}$ Vervolgens is een lijst met uitleveringsdelicten (lijstfeiten) aan het verdrag toegevoegd. Deze lijst is overigens niet uitputtend nu als laatste categorie 'alle andere feiten' worden genoemd, 'maarvoor uitlevering kan morden toegestaan volgens het recht van beide verdragspartijen'. ${ }^{42}$

Het bilaterale NL-VS-verdrag voorziet dus niet uitsluitend in uitlevering bij lijstfeiten, waardoor het EU-VSuitleveringsverdrag geen voorrang kriigt boven het bilaterale NL-VS-uitleveringsverdrag.

Wat betreft de dubbele strafbaarheid gaat het er volgens de Hoge Raad niet om dat de gedraging onder soortgelijke strafbepalingen valt in zowel Amerika als Nederland. Het gaat erom dat het materiële feit waarvoor de uitlevering is verzocht strafbaar is naar zowel het recht van de verzoekende staat als dat van Nederland, ${ }^{43}$ ook al is dat in Amerika het kartelverbod en in Nederland een bedrogsverbod zoals in art. 328bis $\mathrm{Sr}$. Om te kunnen vaststellen dat sprake is van dubbele strafbaarheid moet dus beoordeeld worden of handelen dat naar Amerikaans recht 'price fixing' oplevert ook binnen de bestanddelen valt van art. 328bis Sr. Daarbij is niet van belang dat die buitenlandse strafbaarstelling in alle opzichten overeenstemt met de Nederlandse. Voldoende is dat die buitenlandse strafbaarstelling in de kern hetzelfde rechtsgoed beschermt. Ullings is in de VS uiteindelijk veroordeeld voor overtreding van het Amerikaanse kartelverbod van de Sherman Act (Section 1), dat als volgt luidt: ${ }^{44}$

39. Uitleveringsverdrag tussen het Koninkrijk der Nederlanden en de Verenigde Staten van Amerika, 's-Gravenhage, 24 juni 1980.

40. Toelichtende nota bij het uitleveringsverdrag (TK 1981-1982, 17122 (R1193), nr. 1, p. 2).

41. Art. 2 lid 2 sub a NL-VS-uitleveringsverdrag.

42. T\&C Internationaal Strafrecht, uitleveringsverdrag NL-VS

43. Hoge Raad 30 maart 2004, ECLI:HR:2004:AO4255.

44. Dit blijkt onder meer uit de in 2008 getroffen plea agreement van Martinair met de Amerikaanse autoriteiten. De schikking is te 
'Every contract, combination in the form of trust or othermise, or conspiracy, in restraint of trade or commerce among the several States, or with foreign nations, is declared to be illegal. Every person who shall make any contract or engage in any combination or conspiracy hereby declared to be illegal shall be deemed guilty of a felony, and, on conviction thereof, shall be punished by fine not exceeding \$100,000,000 if a corporation, or, if any other person, $\$ 1,000,000$, or by imprisonment not exceeding 10 years, or by both said punishments, in the discretion of the court. ${ }^{45}$

Dan rijst de vraag: vormt deelname aan een kartel een lijstfeit en/of is er sprake van dubbele strafbaarheid in het bilaterale NL-VS-uitleveringsverdrag? De Bree ${ }^{46}$ gaat in zijn historisch onderzoek van art. 328bis Sr terug tot 1915 en concludeert dat deze bepaling de pendant is van de civielrechtelijke oneerlijke mededinging. Op basis daarvan zou goed kunnen worden beargumenteerd dat een mededingingsrechtelijke gedraging valt onder lijstfeit 20: 'strafbare feiten met betrekking tot het verbod van privaatrechtelijke monopolies of oneerlijke handelspraktijken'. Daarbij moet worden vermeld dat de regering na sluiting van het verdrag aangaf dat het bij dat specifieke lijstfeit ook ging om kartelgedragingen die 'in het Nederlandse recht [maren] ondergebracht in de Wet economische mededinging'. ${ }^{47}$ Ondanks dat die in 1998 is vervangen door de Mededingingswet, toont deze toelichting aan dat deelname aan of betrokkenheid bij een kartel onder lijstfeit 20 valt en waar dubbele strafbaarheid dan niet voor wordt vereist voor uitlevering door Nederland aan de VS.

Als dat niet het geval zou zijn, is het vervolgens de vraag of er sprake is van dubbele strafbaarheid. Zoals blijkt uit de reeds genoemd Piet H.-zaak is kartelgedrag ook in Nederland strafbaar gesteld onder art. 328bis Sr, ook al is dat een dode letter en wordt in Nederland administratiefrechtelijk gehandhaafd. De conclusie luidt dan dat sprake is strafbaarheid in Nederland en - nu dat ook in de VS het geval is - is voldaan aan het vereiste van dubbele strafbaarheid.

Zowel wanneer sprake is van een lijstfeit als bij dubbele strafbaarheid dient het strafbare feit voldoende ernstig te zijn. Die ernst komt tot uitdrukking in de strafmaat, waardoor sprake is van een gekwalificeerde dubbele strafbaarheid. ${ }^{48}$ Art. 2 lid 2 van het NL-VS-uitleveringsverdrag vereist een vrijheidsstraf van meer dan een jaar in beide staten. Op grond van art. 328bis Sr kan een gevangenisstraf van maximaal één jaar worden opgelegd. Daarmee is in Nederland geen sprake van een straf van

raadplegen via: http://lib.law.virginia.edu/Garrett/corporate-prosecu tion-registry/agreements/martinair.pdf.

45. Te raadplegen via: www.law.cornell.edu/uscode/text/15/1

46. R. de Bree, 'Mededingingsrecht en strafrecht: hernieuwde kennismaking', M\&M 2006/7, p. 205 e.v.

47. Toelichtende nota bij het uitleveringsverdrag (TK 1981-1982, 17122 (R1193), nr. 1, p. 9).

48. Toelichtende nota bij het uitleveringsverdrag (TK 1981-1982, 17122 (R1193), nr. 1, p. 2). méér dan een jaar (ook al scheelt dat maar een milliseconde, althans een ondeelbaar moment tussen een 'gevangenisstraf van ten hoogste een jaar' (art. 328bis Sr) en 'een vrijheidsstraf van meer dan een jaar' (art. 2 lid 2 NL-VS Uitleveringsverdrag)). Overigens zou bij de eventuele toepassing van het EU-VS-Uitleveringsverdrag dezelfde gekwalificeerde dubbele strafbaarheid een struikelblok vormen, omdat ook daar een minimale maximumstraf van meer dan een jaar geldt (art. 4 lid 1 EU-VS-Uitleveringsverdrag). Ter herinnering: aan de ex-directrice van Martinair Cargo werd in de VS een gevangenisstraf opgelegd van 14 maanden voor haar deelname aan het kartel, waarbij een maximumgevangenisstraf van tien jaar mogelijk was geweest. ${ }^{49}$

In het geval van mevrouw Ullings is nog noemenswaardig dat zij volgens de Amerikaanse autoriteiten 'conspired with others' ${ }^{50}$. Zij was onderdeel van een groep van eenentwintig bestuurders van luchtvaartmaatschappijen die in dit onderzoek zijn vervolgd. Indien zij daarmee onderdeel zou uitmaken van een criminele organisatie, zou dat de casus mogelijk anders maken. Dat zorgt immers onder het Nederlands strafrecht voor een aanzienlijk hoger strafmaximum. Uitlevering vanwege deelneming aan een dergelijke organisatie kan toelaatbaar worden verklaard voor zover de feiten waarop de organisatie het oogmerk heeft, strafbaar zijn gesteld bij de wetten van de verzoekende staat en zij volgens die van de aangezochte staat eenzelfde inbreuk op de rechtsorde opleveren. ${ }^{51}$ De Hoge Raad oordeelde eerder echter dat 'de deelneming in een vereniging van personen mier doelstelling is gericht op het plegen van een misdrijf het Amerikaanse begrip 'conspiracy' gedeeltelijk dekt, namelijk voor zover naar Nederlands recht sprake is van overtreding van art. $140 \mathrm{Sr}^{52}$ 'Daartoe is nodig dat aannemelijk wordt gemaakt dat de opgeëiste persoon behoort tot een vereniging van personen die zich in algemene zin op het plegen van misdrijven richt.' 53

\subsection{Overlevering binnen de EU}

In de EU zien we een divers pallet van handhavingsregimes ten aanzien van overtredingen van het kartelverbod. Zoals hierboven uiteengezet, (bepaald) kartelgedrag kan in Nederland overtreding van art. 328bis Sr opleveren. In de EU kennen slechts twee lidstaten een algemeen strafrechtelijk regime bij kartelovertredingen: Denemarken en Slovenië (en overigens ook het Verenigd Koninkrijk, maar dat is geen lidstaat meer). In de overige lidstaten leveren niet alle overtredingen van het kartelverbod ook een strafbaar feit op. In sommige lidstaten worden alleen prijsafspraken bij een openbare aanbesteding strafrechtelijk gehandhaafd, zoals in België, Duitsland, Hongarije, Italië en Oostenrijk. In

49. Blijkens het persbericht van de DOJ: www.justice.gov/opa/pr/formerair-cargo-executive-extradited-italy-price-fixing, alsook de betreffende bepaling: 15 U.S. Code §1

50. https://archives.fbi.gov/archives/washingtondc/press-releases/2010/ wfo092110a.htm.

51. HR 18 juni 2002, ECLI:NL:HR:2002:AE2114

52. HR 30 mei 1978, ECLI:NL:PHR:1978:AC6275, NJ 1979, 11

53. HR 30 maart 2004, ECLI:HR:2004:AO4255 
andere lidstaten wordt alleen kartelgedrag dat als fraude kan worden aangemerkt strafrechtelijk vervolgd, zoals in Frankrijk, Griekenland en Roemenië. Dat doet de vraag rijzen of Nederland een inwoner van Nederland (al dan niet Nederlands staatsburger) kan overleveren aan een andere lidstaat wanneer sprake is van een verdenking van kartelgedrag.

Indien een EU-lidstaat de vervolging naar iemand die zich in een andere lidstaat ophoudt, zou wensen in te stellen voor overtredingen van het mededingsrecht, dan dient hiertoe een Europees aanhoudingsbevel (EAB) te worden uitgevaardigd. Indien de verdachte in kwestie vervolgens wordt aangetroffen op ons territoir, kan de lidstaat waar hij of zij gezocht wordt een schriftelijk verzoek doen tot (vervolgings)overlevering naar die lidstaat. Dat kan weer alleen als er sprake is van een lijstfeit of van dubbele strafbaarheid. Bij een lijstfeit dient een naar het recht van de uitvaardigende lidstaat benoemd strafbaar feit waarop een vrijheidsbenemende straf met een maximum van ten minste drie jaren is gesteld tevens op de in bijlage 1 bij de Overleveringswet behorende lijst te zijn vermeld. De categorieën van strafbare feiten leiden tot overlevering ' $z$ onder toetsing van de dubbele strafbaarheid van het feit'. Indien de uitvaardigende justitiële autoriteit het in het $\mathrm{EAB}$ vermelde feit als een lijstfeit heeft aangeduid, mag de uitvoerende justitiële autoriteit niet onderzoeken of dat feit strafbaar is naar het recht van de uitvoerende lidstaat. Op grond van het beginsel van wederzijdse erkenning en gelet op het hoge niveau van vertrouwen en solidariteit tussen de lidstaten heeft de Raad van de EU overwogen dat de categorieën van feiten hetzij naar hun aard, hetzij naar hun strafbedreiging 'feiten zijn die op zodanig ernstige wijze de openbare orde verstoren en de openbare veiligheid in gevaar brengen, dat meglating van de toetsing van de dubbele strafbaarheid gerechtvaardigd is'. ${ }^{54}$

Wanneer geen sprake is van een lijstfeit, kan toch tot overlevering worden overgegaan wanneer sprake is van dubbele strafbaarheid wanneer in de uitvaardigende lidstaat een vrijheidsbenemende straf geldt met een maximum van ten minste twaalf maanden. ${ }^{55}$ Wanneer Nederland in dat geval de overleverende lidstaat is, is de strafmaat alhier irrelevant. ${ }^{56}$ De Minister van Veiligheid en Justitie heeft aangekondigd dat hij voornemens is de tekst van art. 7 lid 1 OLW aan te passen, zodat daaruit duidelijk blijkt dat de voorwaarde inzake de strafbedreiging alleen geldt voor de uitvaardigende lidstaat. ${ }^{57}$ Ingevolge art. 6 lid 1 Overleveringswet is het toegestaan onderdanen over te leveren, maar alleen onder de garantie dat zij de eventueel opgelegde vrijheidsstraf in Nederland mogen ondergaan. (Advocaten voor de Wereld); zie ook N. Rozemond, 'De geldigheid van het Kaderbesluit betreffende het Europees aanhoudingsbevel en de legaliteit van de regeling van de "lijstfeiten"', Nederlands tijdschrift voor Europees Recht NtER 2008/10, p. 285 e.v.

55. Art. 7 lid 1 sub 2 onder 2 Overleveringswet.

56. Rechtbank Amsterdam 30 oktober 2015, ECLI:NL:RBAMS:2015:7460.

57. Kamerstukken // 2015/16, 32317, 351, p. 2.
Ten aanzien van kartelgedrag is de eerste vraag of er sprake is van een lijstfeit. Ten eerste dient de gedraging strafbaar te zijn in het strafrecht van de uitvaardigende lidstaat met een vrijheidsbenemende straf met een maximum van ten minste drie jaren. Zoals gezegd, handhaaft een tiental lidstaten het mededingingsrecht namelijk - in meer of minder mate - via het strafrecht. Hamvraag blijft evenwel of kartelgedrag daarnaast ook op de lijst voorkomt. Als zodanig wordt het niet benoemd in bijlage 1 bij de Overleveringswet. Wel worden fraude en bescherming van financiële belangen van de EU genoemd als lijstfeiten. Wat betreft dat laatste zou een biedkartel bij een aanbesteding waarbij EU-fondsen zijn gemoeid onder dat lijstfeit kunnen vallen. ${ }^{58}$ Terug naar Piet H. In 1984 toen de Hoge Raad over het klein hulpverzoek oordeelde bestond het EAB nog niet. Maar wellicht had Duitsland vandaag de dag niet alleen om rechtshulp, maar ook om overlevering hebben verzocht. Het bedrog waar Piet $H$. in Duitsland van werd verdacht zou nu onder het Kaderbesluit EAB kwalificeren als het lijstfeit fraude en wordt in Duitsland thans bestraft met een vrijheidsbenemende straf van maximaal vijf jaar ( $\$ 263 \mathrm{StGB})$. Dat is meer dan de in het kaderbesluit inzake $\mathrm{EAB}$ vereiste maximumstraf van ten minste drie jaar. Buiten het specifieke geval van fraude, lijkt kartelgedrag niet als lijstfeit te kwalificeren. Oneerlijke concurrentie komt, zoals gezegd, in het uitleveringsverdrag NL-VS wel als lijstfeit voor, maar dus niet in het Kaderbesluit EAB.

Vervolgens is het de vraag of er sprake is van dubbele strafbaarheid wil overlevering plaats kunnen vinden. Net als in bovenstaande analyse onder het uitleveringsverdrag met de VS en de zaak van Piet H. kan kartelgedrag in Nederland worden bestraft onder art. 328bis Sr. De toets van de gekwalificeerde dubbele strafbaarheid aan de hand van een minimumgevangenisstraf werkt onder het Kaderbesluit EAB evenwel anders dan bij een uitleveringsverdrag, zoals met de VS. Er wordt alleen getoetst of er minimaal een vrijheidsbenemende straf geldt met een maximum van twaalf maanden in de uitvaardigende staat. De strafmaat in de overleverende lidstaat is daarmee niet relevant. Overlevering kan dan plaatsvinden wanneer (1) het kartelgedrag in beide staten strafbaar is gesteld (2) in de uitvaardigende staat wordt bestraft met een vrijheidsbenemende straf van meer dan 12 maanden en (3) die straf in Nederland kan worden uitgezeten. Overlevering bij verdachten van kartelgedrag is dus allerminst uitgesloten. Dat art. 328bis $\mathrm{Sr}$ in Nederland een maximumstraf kent van maximaal 12 maanden is dus irrelevant, omdat alleen de maximumstraf in de verzoekende staat leidend is.
58. M. Engelhart, 'The Case Study of Germany', in: I. Sammut, J. Agranovska (red.), Implementing and Enforcing EU Criminal Law Theory and Practice, Den Haag: Eleven International Publisihing 2020, p. 77 e.v., op p. 85. 


\section{Nederland levert toch geen eigen onderdanen uit?!}

Uit- en overlevering wegens een kartelgedraging is wel degelijk mogelijk, omdat die gedraging als lijstfeit is opgenomen, of omdat er sprake is van dubbele strafbaarheid. Soms kent de nationale wetgeving van staten of verdragen expliciete uitzonderingsgronden met betrekking tot eigen onderdanen (nationaliteitsexceptie). De reden bij weigering ter vervolging van een eigen onderdaan zou erin zijn gelegen burgers te beschermen tegen een buitenlands strafrechtstelsel in een vreemde taal waardoor verdediging moeilijker is. ${ }^{59} \mathrm{Bij}$ weigering ter bestraffing van een eigen onderdaan is de reden dat re-integratie gemakkelijker verloopt wanneer de vrijheidsbenemende straf wordt uitgezeten in de woonstaat. ${ }^{60}$ Dat is evenwel niet een uitzonderingsgrond die altijd en overal geldt. Als er al een dergelijke uitzonderingsgrond bestaat voor eigen onderdanen rijst in EUverband de vraag of dan ook burgers van andere lidstaten die EU-burger zijn niet gelijk dienen te worden behandeld om een ongerechtvaardigde discriminatie te voorkomen.

\subsection{Uitlevering eigen onderdanen aan de VS}

Het feit dat de Meta Ullings op vakantie in Italië is aangehouden en uiteindelijk uitgeleverd aan de VS doet de vraag rijzen waarom zij niet - al veel eerder - door Nederland was overgedragen. Uit de niet te misverstane woorden van het persbericht van de DOJ zaten zij al langer achter haar aan en waren zij erg verheugd dat zij, als 'price fixer', 'was brought to justice'. ${ }^{61}$

Openbare bronnen maken geen melding van een eventueel verzoek van de VS an Nederland voor de uitlevering van mevrouw Ullings. Mogelijk is een dergelijk verzoek nooit gedaan. Overigens is dit niet omdat Nederland per definitie geen onderdanen uitlevert als gevolg waarvan een dergelijk verzoek bij voorbaat kansloos zou zijn. Zoals Paridaens opmerkt: 'in relatie tot de Verenigde Staten [kan] het meest' ${ }^{62}$ Ingevolge art. 8 Uitleveringsverdrag NL-VS mag uitlevering ter fine van strafvervolging van eigen onderdanen niet worden geweigerd op de enkele grond van de nationaliteit van de opgeëiste persoon. Eigen onderdanen worden echter alleen uitgeleverd indien voldoende is gewaarborgd dat ze in geval van veroordeling tot een vrijheidsstraf in de gelegenheid zullen worden gesteld hun (verdere) straf in

59. Conclusie van A-G Bot, 10 mei 2016, C-182/15 (Petruhhin), ECLI:EU:C: 2016:330, par. 51.

60. HvJEU 17 juli 2008, C-66/08 (Kozłowski), ECLI:EU:C:2008:437, r.o. 45.

61. De exacte tekst van het dit onderdeel van het persbericht luidt als volgt: 'The Division appreciates the cooperation of the Italian authorities in this matter. With the assistance of our law enforcement colleagues at home and around the world, the Division will aggressively pursue every avenue available in bringing price fixers to justice.'

62. D.J.M.W. Paridaens, 'De uitlevering van eigen onderdanen door Nederland', in: C.H. Brants, C. Kelk \& M. Moerings, Er is meer; Opstellen over mensenrechten in internationaal perspectief, Deventer: Gouda Quint 1996, p. 117
Nederland te ondergaan. ${ }^{63}$ Doordat de VS zijn toegetreden tot het Verdrag inzake de overbrenging van gevonniste personen (VOGP) waarbij ook Nederland partij is, kunnen onderdanen, na te zijn uitgeleverd, in geval van veroordeling in de VS terugkeren naar Nederland om hun straf verder hier te ondergaan. De VS hebben een algemene terugkeergarantie voor Nederlandse onderdanen gegeven, waarbij zij ermee akkoord gaan dat de in de VS opgelegde vrijheidsstraf wordt omgezet door de Nederlandse rechter en naar Nederlandse maatstaven. ${ }^{64}$

\subsection{Uitlevering andere EU-onderdanen aan de VS}

In Nederland bestaat dus geen absoluut verbod op het uitleveren van eigen onderdanen. In Duitsland bestaat een dergelijk verbod wel; dat is zelfs grondwettelijk en er is tevens in voorzien in het bilaterale uitleveringsverdrag met de VS. Maar Duitsland levert wel onderdanen van andere EU-lidstaten uit, net als Italië de Nederlandse Ullings uitleverde. In dat verband rijst de vraag of dat verschil van behandeling niet in strijd is met het discriminatieverbod jegens EU-burgers van art. 19 Verdrag betreffende de Werking van de EU (VWEU). In dat verband is de Pisciotti-zaak van belang.

De Italiaan Pisciotti was de eerste persoon die uitsluitend voor een kartelinbreuk an de Verenigde Staten werd uitgeleverd. ${ }^{65} \mathrm{Hij}$ is een Italiaans staatsburger en was directeur van een producent van olieslangen voor maritieme toepassingen (die worden gebruikt voor het overpompen van gas en olie van en naar schepen). Tussen diverse producenten van die slangen werd een kartel bewezen geacht door verschillende mededingingsautoriteiten. Niet alleen de Amerikaanse autoriteiten kwamen tot die conclusie, maar ook de Europese Commissie die de producenten beboette. ${ }^{66}$ De VS had een internationaal aanhoudingsbevel tegen hem uitgevaardigd. Bij een tussenlanding van zijn vlucht van Nigeria naar Italië op de Duitse luchthaven van Frankfurt am Main werd Pisciotti aangehouden door de Duitse federale politie. Uiteindelijk werd hij door Duitsland uitgeleverd aan de VS op grond van het uitleveringsverdrag tussen de EU en de VS. Hij pleitte daar schuldig en zat een gevangenisstraf uit van twee jaar, onder aftrek van de hechtenis ondergaan in Duitsland. Juridische procedures tegen de uitlevering mochten niet baten, waarop hij Duitsland civielrechtelijk ansprakelijk probeerde te stellen wegens ongeoorloofde discriminatie, omdat Duitse onderdanen niet worden uitgeleverd. De Duitse civiele rechter die over de schadevergoedingsvordering diende te oordelen, stelde daarover prejudiciele vragen aan het Hof van Justitie van de EU

63. Zie art. 4 lid 2 Uitleveringswet.

64. T\&C Internationaal Strafrecht, uitleveringsverdrag NL-VS.

65. Persbericht van het Department of Justice van 4 april 2014, 'First Ever Extradition on Antitrust Charge - Former Marine Hose Executive Extradited from Germany to Face Charges of Participating in Worldwide BidRigging Conspiracy', te raadplegen op www.justice.gov/opa/pr/firstever-extradition-antitrust-charge.

66. Beschikking van de Europese Commissie van 28 januari 2009 in zaak COMP/39406. 
(HvJEU). ${ }^{67}$ In een grote kamer oordeelde het HvJEU daarover dat het onderscheid tussen eigen onderdanen en andere EU-burgers weliswaar een nadelig effect heeft op het vrij verkeer van EU-burgers van art. 21 VWEU, maar dat dat kan worden gerechtvaardigd. Die rechtvaardiging is volgens het $\mathrm{HvJEU}$ aanwezig, omdat zo straffeloosheid wordt voorkomen. De belemmerende maatregel mag daarnaast niet verder gaan dan strikt noodzakelijk. Een minder vergaande maatregel zou zijn geweest dat Italië om overlevering had verzocht op basis van het Kaderbesluit EAB om tot vervolging over te gaan. Daarmee gaat het Kaderbesluit dus voor op het EU-VS uitleveringsverdrag. Duitsland had Italië wel op de hoogte gesteld, maar Italië had vervolgens niet om overlevering verzocht, waarna Pisciotti werd uitgeleverd. Volgens het HvJEU had Duitsland het EU-recht daarom niet geschonden, ondanks dat het zijn eigen burgers anders behandelt dan andere EU-burgers.

Als we de Pisciotti-zaak transponeren naar de Ullingszaak rijst de vraag of Italië Ullings wel had mogen uitleveren en of de Nederlandse consulaire autoriteiten eerst op de hoogte hadden moeten worden gesteld, zodat Nederland de mogelijkheid zou hebben gehad een EAB uit te vaardigen. We weten niet of dat is gebeurd. Italië levert evenwel ook eigen onderdanen uit als er een uitleveringsverdrag is; er is geen (grondwettelijk) uitleveringsverbod, zoals in Duitsland. In dat geval is er geen onderscheid tussen Italiaanse burgers en andere EUburgers, zoals Ullings, en is er dus ook geen sprake van discriminatie. En in dat geval hoeft de lidstaat waarvan de uit te leveren persoon de nationaliteit heeft ook niet op de hoogte te worden gesteld wil er sprake zijn van een gerechtvaardigde discriminatie, zoals in de Pisciottizaak het geval was.

In de Pisciotti-zaak ging het om vervolging van een EUburger. Wat betreft uitlevering vanwege de uitvoering van een straf lag het anders in de Raugevicius-zaak. Hij verbleef al geruime tijd in Finland en had aldaar ook zijn gezin (zijn kinderen hadden de Finse nationaliteit). Rusland verzocht om zijn uitlevering voor het uitzitten van een straf vanwege een drugsdelict. De Finse nationale wet voorziet in een verbod op uitlevering van eigen onderdanen en in de mogelijkheid de straf uit te zitten in Finland. Volgens het HvJEU moest Raugevicius om verboden discriminatie te voorkomen dezelfde

67. HvJEU 10 april 2018, C-191/16 (Romano Pisciotti / Bundesrepublik Deutschland), ECLI:EU:C:2018:222. Daarnaast had Pisicotti de Commissie verzocht een inbreukprocedure in te stellen tegen Duitsland wegens schending van het EU-recht. De Commissie wees die klacht af, waartegen Pisciotti in beroep ging bij het Gerecht van de EU die zijn beroep niet-ontvankelijk verklaarde en daarna eveneens tevergeefs in hogere voorziening bij het HvJEU; beschikking HvJEU 28 januari 2015, C-411/14 (Romano Pisciotti / Europese Commissie), ECLI:EU:C: 2015:48. Zie ook: A.J. de Vries, 'De opmars van het uitleveringsrecht in de rechtspraak van het Hof van Justitie - het arrest Pisciotti nader beschouwd in het licht van eerdere Europese jurisprudentie en de Nederlandse uitleveringspraktijk', Nederlands tijdschrift voor Europees Recht NtER 2018-7-8, p. 234; E. Filius, ‘De zoektocht naar de balans tussen Unierechtelijke verplichtingen en de naleving van internationale overeenkomsten met derde landen', DD 2018/57. behandeling worden gegund als Finse staatsburgers. ${ }^{68}$ Vanwege zijn permanente verblijf en integratie aldaar was hij vergelijkbaar met Finse burgers. Weliswaar werd in die zaak dezelfde rechtvaardigingsgrond ingeroepen als in de Pisciotti-zaak: het diende straffeloosheid te voorkomen. Dat accepteerde het HvJEU die niet, omdat die straffeloosheid juist werd voorkomen, doordat er de mogelijkheid was de straf op Fins grondgebied uit te zitten. Die mogelijkheid moest Raugevicius ook worden geboden om discriminatie te voorkomen.

De Nederlandse regering is mede naar aanleiding van de Pisciotti- en Raugevicius-zaken voornemens om de overen uitleveringswetten aan te passen met het wetsvoorstel herimplementatie Kaderbesluit EAB. ${ }^{69}$ Ondanks dat Nederland de meeste andere EU-onderdanen op dezelfde manier behandelt als Nederlandse staatsburgers waar het uitlevering aan derde landen betreft, ${ }^{70}$ wenst het voor die gevallen waarin dat niet zou geschieden toch het systeem te introduceren waarbij overlevering voorrang krijgt op uitlevering.

\subsection{Overlevering binnen de EU}

Tot slot verdient het nog bespreking of eigen onderdanen moeten worden overgeleverd op grond van een EAB. Het systeem van het Kaderbesluit EAB berust op wederzijdse erkenning. Terwijl juist de ratio om eigen burgers niet uit te leveren volgens Glerum berust op 'mantroumen, althans onvoldoende vertroumen in de deugdelijkheid van buitenlandse rechtsstelsels' ${ }^{71}$ Wederzijdse erkenning gaat juist uit van vertrouwen. Het Kaderbesluit kent daarom geen uitzondering op de verplichting eigen burgers niet uit te leveren, tenzij de lidstaat van die onderdaan zelf de straf uitvoert. Volgens de Europese Commissie was de overlevering van eigen onderdanen 'een belangrijke vernieuming' van het $\mathrm{EAB} .{ }^{72}$ Nederland heeft die facultatieve uitzonderingsgrond uit het Kaderbesluit EAB geimplementeerd in art. 6, leden 2 en 3 Overleveringswet. Om discriminatie te voorkomen kunnen ook andere EU-burgers die over een permanente verblijfsvergunning op grond van de Vreemdelingenwet beschikken van dezelfde weigeringsgrond gebruiken maken op grond van art. 6 lid 5 Overleveringswet. In de Wolzenburg-zaak oordeelde het HvJEU overigens over deze Nederlandse bepaling dat de eisen uit de Vreemdelingenwet voor een permanente verblijfsvergunning te ver gingen om discriminatie te voorkomen. De eis van een verblijf van vijf jaar om aan

68. HvJEU 13 november 2018, C-247/17 (Denis Raugevicius), ECLI:EU:C: 2018:898.

69. Stcrt. 2020, 38892.

70. Artikelsgewijze toelichting op artikel 2 Overleveringswet en op artikel 22b Uitleveringswet, Memorie van Toelichting (Stcrt. 2020, 38892, p. $15-16$ en 26).

71. V.H. Glerum, De weigeringsgronden bij uitlevering en overlevering Een vergelijking en kritische evaluatie in het licht van het beginsel van wederzijdse erkenning, Nijmegen: Wolf Legal Publishers 2013, op. p. 466.

72. Verslag van de Commissie op grond van artikel 34 van het kaderbesluit van de Raad van 13 juni 2002 betreffende het Europees aanhoudingsbevel en de procedures van overlevering tussen de lidstaten (COM/ 2006/0008 def), par. 2.2.1. 
te nemen dat er voldoende integratie was met de Nederlandse samenleving achtte het HvJEU aanvaardbaar, maar additionele administratieve verplichtingen niet. ${ }^{73}$ De Nederlandse regering is voornemens om de overleveringswet ook op dit punt aan te passen met het wetsvoorstel herimplementatie Kaderbesluit EAB. ${ }^{74}$

\section{Conclusie}

De recente uitlevering van de Nederlandse ex-directrice van Martinair Cargo, Meta Ullings, laat zien dat, hoewel in Nederland het mededingingsrecht bestuursrechtelijk wordt gehandhaafd, aan mededingingsrechtelijke overtredingen voor Nederlanders strafrechtelijke risico's kunnen kleven. Indien dergelijke overtredingen door Nederlandse onderdanen in het buitenland effect hebben, kunnen Nederlanders in het buitenland strafrechtelijk worden vervolgd en worden veroordeeld.

Die strafrechtelijke risico's zijn terug te voeren naar welgeteld één bepaling in ons Wetboek van Strafrecht die oneerlijke concurrentie strafbaar stelt, waaronder het vormen van bepaalde kartels. Dat het mededingingsrecht in Nederland bestuursrechtelijk worden gehandhaafd, doet daar niets aan af. De zaak Piet H., waar sprake was van een biedkartel, laat zien dat deze vanuit handhavingsperspectief dode letter kan leiden tot de, in het internationale strafrecht vereiste, dubbele strafbaarheid waardoor hij voor sommigen de nagel aan hun doodskist betekent.

Voor de mogelijkheden van uitlevering vanuit Nederland aan de VS zijn we te rade gegaan bij het uitleveringsverdrag NL-VS. Hoewel wel sprake is van de vereiste dubbele strafbaarheid, ontbreekt de voldoende mate van ernst, nu op overtreding van art. 328bis $\mathrm{Sr}$ niet een gevangenisstraf van meer dan één jaar staat, maar slechts een gevangenisstraf van maximaal één jaar. Desalniettemin is kartelgedrag aan te merken al een lijstfeit onder het uitleveringsverdrag NL-VS, waardoor uitlevering toch mogelijk is. Bij een lijstfeit hoeft de toets van gekwalificeerde dubbele strafbaarheid niet te worden toegepast.

Ingevolge het Uitleveringsverdrag NL-VS mag uitlevering ter fine van strafvervolging van eigen onderdanen niet worden geweigerd op de enkele grond van de nationaliteit van de opgeëiste persoon. Onderdanen worden echter alleen uitgeleverd indien voldoende is gewaarborgd dat ze in geval van veroordeling tot een vrijheidsstraf in de gelegenheid zullen worden gesteld hun (verdere) straf in Nederland te ondergaan. De VS hebben een algemene terugkeergarantie voor Nederlandse onderdanen gegeven, waarbij zij ermee akkoord gaan dat de in de VS opgelegde vrijheidsstraf wordt omgezet door de Nederlandse rechter en naar Nederlandse maatstaven.

EU-breed bestaat een divers pallet aan handhavingsregimes ten aanzien van overtredingen van het kartelverbod. Er zijn lidstaten met een algemeen strafrechtelijk regime bij kartelovertredingen. In sommige lidstaten worden alleen prijsafspraken bij een openbare aanbesteding strafrechtelijk gehandhaafd. In andere lidstaten wordt alleen kartelgedrag strafrechtelijk vervolgd dat als fraude kan worden aangemerkt. Dit was aanleiding voor de vraag of Nederland een onderdaan kan overleveren wanneer sprake is van een verdenking van kartelgedrag. Hiervoor dient sprake te zijn van een lijstfeit of van dubbele strafbaarheid. Een biedkartel bij een aanbesteding, waarbij EU-fondsen zijn gemoeid, zou eventueel onder een lijstfeit kunnen vallen. Maar buiten dat specifieke geval lijkt kartelgedrag niet als lijstfeit te kwalificeren. Er is wel sprake van dubbele strafbaarheid, waardoor overlevering bij verdachten van kartelgedrag mogelijk is, zonder dat hoeft te worden gekeken naar de strafmaat in Nederland.

Hoewel de uitlevering van onderdanen door Nederland mogelijk is, zijn er lidstaten die hierop een verbod hebben. Deze deinzen er vervolgens echter niet voor terug om onderdanen van andere EU-lidstaten uit te leveren, tenzij de lidstaat waarvan de desbetreffende persoon onderdaan is na informering een $\mathrm{EAB}$ uitvaardigt voor dezelfde feiten. Dit levert overigens een discriminatie van EU-burgers op. Hoewel dat onderscheid tussen eigen onderdanen en andere EU-burgers een nadelig effect heeft op het vrij verkeer van EU-burgers, kan dat worden gerechtvaardigd, aangezien zo straffeloosheid wordt voorkomen. Overigens levert Italië ook eigen onderdanen uit als er een uitleveringsverdrag is, zodat er ten aanzien van Ullings sowieso geen sprake was van discriminatie. 